\title{
MATHEMATICAL MODELLING AND PERFORMANCE ANALYSIS OF DIFFERENT SOLAR AIR COLLECTORS
}

\author{
M.A. KARIM AND Z.M. AMIN \\ Mechanical Engineering Discipline, Science and Technology Faculty, \\ Queensland University of Technology, Australia. \\ azharul.karim@qut.edu.au,andzakaria.amin@gut.edu.au
}

(Received: Sept. 10, 2015; Accepted: Oct. 15, 2015; Published on-line: Nov. 30, 2015)

\begin{abstract}
The purpose of using solar air collectors is to raise the atmospheric air temperature to a temperature which can be used for various low and medium temperature applications. Collector, absorber and airflow arrangement are the most important components in the solar air collector. The performance of the collector depends on its heat loss and the absorber area that is in contact with the airflow. This study involves the theoretical simulation of the effect of mass flow rate on the performance, for flat plate and v-groove collectors that are in single and double pass configurations. Results show that the v-groove double pass air collector has the highest efficiency value of 56\% at $0.06 \mathrm{~kg} / \mathrm{m}^{3} \mathrm{~s}$. The performance is greater than flat plate double pass collector, which has an efficiency of $54 \%$ under the same operating conditions.
\end{abstract}

ABSTRAK: Tujuan menggunakan pengumpul udara solar adalah untuk meningkatkan suhu udara atmosfera kepada suhu yang boleh digunakan untuk pelbagai aplikasi suhu rendah dan sederhana. Absorber pemungut dan susunan aliran udara adalah komponen yang paling penting pada pemungut udara solar. Prestasi pengumpul bergantung kepada kehilangan haba dan kawasan penyerap yang melekat hubungan dengan aliran udara itu. Kajian ini melibatkan simulasi teori kesan kadar aliran jisim kepada prestasi, untuk plat rata dan v-alur pengumpul yang dalam konfigurasi pas tunggal dan berganda. Keputusan menunjukkan bahawa v-alur dua pengumpul udara pas mempunyai nilai kecekapan tertinggi sebanyak $56 \%$ pada $0.06 \mathrm{~kg} / \mathrm{m}^{3} \mathrm{~s}$. Prestasi yang lebih besar dari plat rata pengumpul pas dua kali, yang mempunyai kecekapan 54\% di bawah keadaan operasi yang sama.

KEYWORDS: solar air collector; flat plate collector (fpc); v-groove collector; efficiency; single pass; double pass

\section{INTRODUCTION}

Solar energy is a solution to the increasingly limited fossil fuel resources problem. The solar collector is one of the most important components of solar energy systems. The energy of the solar radiation is in this case converted to heat with the use of the solar panel [1]. Solar air collectors have been used for several applications which include space heating, food drying, swimming pool heating, thermal industrial process and solar drying. Attention has been given to the renewable energy sources due to several factors including environmental issues and limited resources of fossil fuel [2]. Converting solar radiation into heat is one of the most common applications of solar energy [3]. 
The purpose of using solar air collectors is to raise the atmospheric air temperature to a higher temperature which can be used in different applications [4]. As the air passes through the solar collector, the heat that is gained by the sun's radiation will be transferred to the air thereby raising its temperature. There are several designs of solar air collectors which are used in different applications. The designs are based on the required heat capacity. The efficiency of collectors in air heating is low due to low convective heat transfer coefficients between absorber and heat losses to the surrounding through the top cover [4]. In order to improve the performance of the collector, flow arrangement could be changed to reduce the heat loss and the absorber shape could be changed to a v-groove of finned shape to increase the absorbent area.

This study was conducted to determine the efficiency of flat plate and v-groove solar collectors with different air flow arrangement by analysing the mathematical equations.

There are many alternative designs for solar air collectors. A good design must be able to minimize heat losses from the collector in order to increase its operating efficiency. The three main features in the collector are the top cover, absorber, and coating [6]. Top cover transmissivity ( $\tau=$ fraction transmitted) which transmits the sunlight is made of glass or plastic. There could be some heat loss by radiation and convection to the ambient since the air is in contact with the glazed layer. The absorptivity ( $\alpha=$ fraction absorbed) which is based on the absorber type, and the coating $(\varepsilon=$ emittance) are the other main features. Absorptivity varies with wavelength, which is very important when dealing with absorbed solar radiation and ambient temperature radiation on the same surface [6]. In addition to this, reflectivity ( $\rho=$ fraction reflected), is the parameter which refers to the amount of sunlight that is reflected by the glazed surface.

The idea of the absorber is to convert the solar radiation to heat. The performance of the absorber also depends on the coating which is the surface that is facing the radiation [7]. Dark colour paint or selective coating is used for the absorber as well as porous cloth material.

This study looks at the mathematical equations of flat plate and v-groove solar air collectors with single and double pass mass flow to determine the thermal efficiency of each collector type. There are several factors that will affect the efficiency of the collector; therefore, these collectors will be tested under the same operating conditions. MATLAB software is used to run the simulations for these collectors.

\section{COLLECTOR TYPES}

\subsection{Flat Plate Collector (FPC)}

The flat plate collector (FPC) is one of the common solar collector designs. The system basically is a metal box that has a glass or plastic cover on the top and an absorber plate on the bottom. Different materials can be used for the absorber plate such as copper, aluminium and steel. Insulation is used in the back of the collector to minimise the heat losses. The insulation should be selected such that it does not melt, shrink or outgas at high temperatures of up to $200^{\circ} \mathrm{C}$ [7]. The FPC is usually used for applications with low or medium temperature range between ambient temperatures of 60 to $100^{\circ} \mathrm{C}$ [5].

The idea of the system is that the inlet air will heat up via the absorber plate when passing through it. The purpose of the absorber plate is to absorb the radiation from the sun. FPC collector designs have different airflow patterns including single pass which could be from the top or below or double pass flow. 
For the top flow case the air flow passes above the absorber plate as shown in Fig. 1. The air flows between the glazed and the absorber plate. The efficiency in this case is low because the air is in contact with the glass cover which results to heat losses to the ambient air.

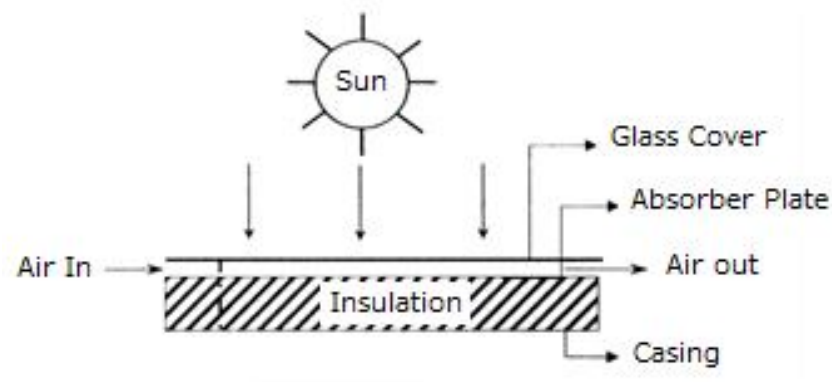

Fig. 1: Top Flow Flat Plate Absorber [5].

The advantages of this type is that it has simple construction and cheap. However, it has only one surface that can transfer heat and has high heat losses. Double-glazed glass can be used to reduce the heat losses but it also decreases the solar radiation.

The configuration where the air flow passes below the absorber is commonly used in solar air collectors. As shown in Fig. 2, a plate parallel to the absorber plate is provided for insulation. This increases the heat transfer surface area to the air stream. In the double pass flow case, the air flow passes on both sides of the absorber as can be seen in Fig. 3. The advantage of this system is that it has double the effective heat transfer area which increases the heat transfer to the air [5]. This type of flow arrangement can also be applied to v-groove and finned collectors.

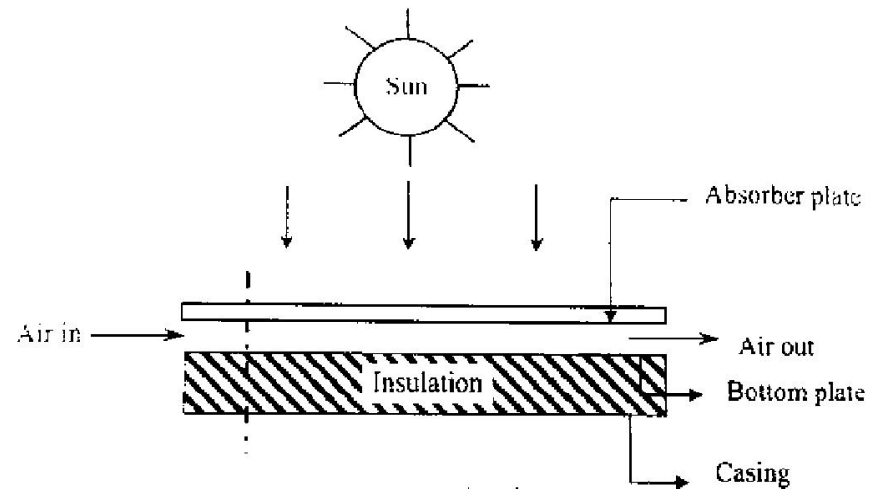

Fig. 2: Bottom Flow Flat Plate Absorber [5].

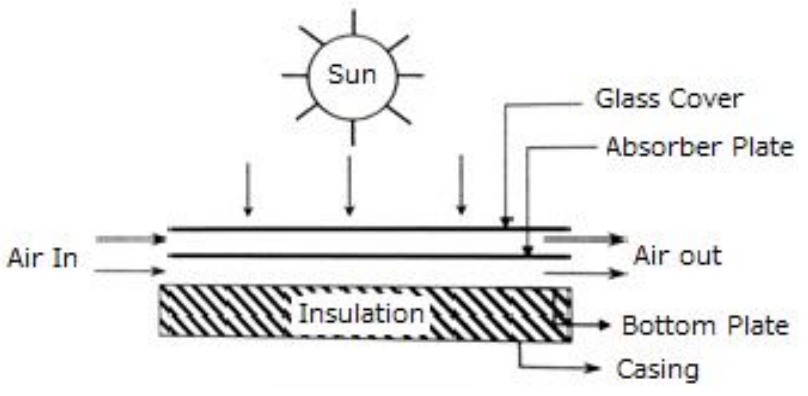

Fig. 3: Double pass Flow Flat Plate Absorber [5]. 


\subsection{V-Groove Collector}

Since the heat transfer between the absorber plate and the flowing air is low on the flat plate collector, this configuration results in less air being heated. In order to improve the performance of the system, the v-groove plate was used as the absorber. In this type of collector, the solar radiation passes through the glass to the absorber, which in this case is a v-groove as shown in Fig. 4. This type of collector can operate in single or double pass mass flow. According to the past research, a v-grooved absorber with double flow has 4$5 \%$ additional efficiency compared to that of the single mode [10].

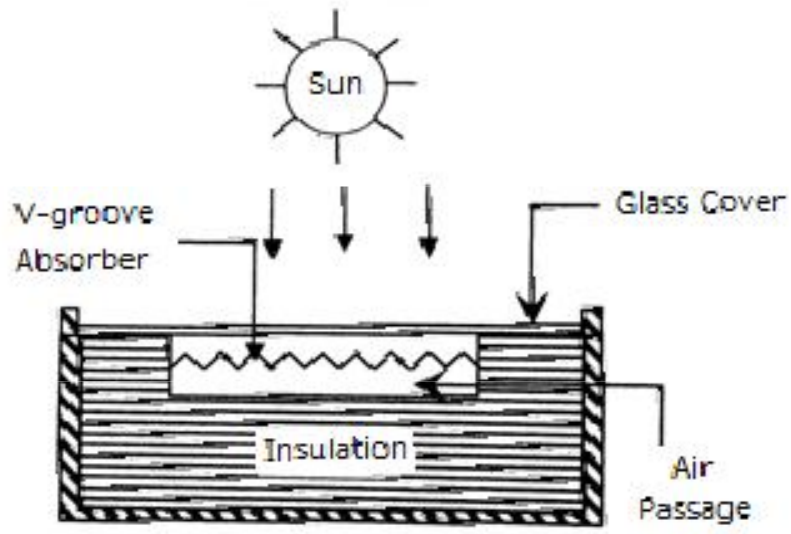

Fig. 4: V-groove Collector [5].

\section{MATLAB SIMULATION}

\subsection{Flat Plate Collector (FPC)}

In order to simplify the collector modelling, the following assumptions were made.

- The collectors are at steady state thermal performance.

- The temperature drop through the glass cover, absorbing plate, and bottom plate are negligible.

- The heat flow through the back insulation is one-dimensional, that is the direction perpendicular to the air flow.

- The sky is assumed to be a blackbody for long-wavelength radiation at an equivalent sky temperature.

- The front and back surfaces losses are the same as the ambient temperature.

- Dust and dirt on the collectors are considered negligible in its effect of shading of the collector absorbing plates.

- The thermal inertia of collector components is neglected.

- The operating temperatures of collector components and mean air temperatures in air channels are assumed to be uniform.

- Temperature of the air varies only in the flow direction.

- The channels are free of air leakage.

- The thermal losses through the collector backs are neglected. 


\subsection{Flat Plate and V-Groove Collector Single Pass Equations}

An iterative matrix method using MATLAB is used to calculate the temperatures. The temperatures will be assumed in the initial stage to determine the heat transfer coefficients and heat losses from the collector. The energy balance equations in the matrix form are used to calculate the new temperature of $\mathrm{T}_{\mathrm{c}}, \mathrm{T}_{\mathrm{ap}}, \mathrm{T}_{\mathrm{bp}}, \mathrm{T}_{\mathrm{f} 1}$ and $\mathrm{T}_{\mathrm{f} 2}$. The values of these parameters will be obtained numerically with an iteration method. Once the new temperatures are found, the equations given below can be used. The equations from [3] will be used to calculate the thermal performance using the matrix method. The thermal network for single pass air collector is illustrated in Fig. 5 below:

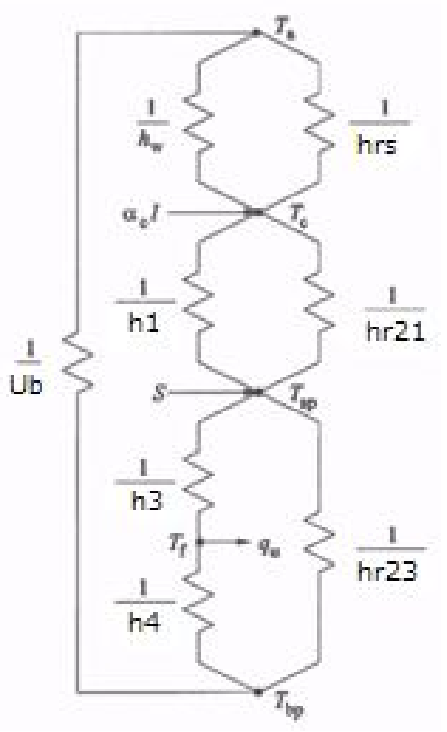

Fig. 5: Thermal network for the single cover solar air collector.

The energy balance in the glass cover is:

$\mathrm{S}_{1}+\left(\mathrm{h}_{1}+\mathrm{h}_{\mathrm{r} 21}\right)\left(\mathrm{T}_{\mathrm{ap}}-\mathrm{T}_{\mathrm{c}}\right)=\left(\mathrm{h}_{\mathrm{w}}+\mathrm{h}_{\mathrm{rs}}\right)\left(\mathrm{T}_{\mathrm{c}}-\mathrm{T}_{\mathrm{a}}\right)$

Energy balance on the absorbing plate is:

$\mathrm{S}_{2}=\left(\mathrm{h}_{1}+\mathrm{h}_{\mathrm{r} 21}\right)\left(\mathrm{T}_{\mathrm{a}}-\mathrm{T}_{\mathrm{c}}\right)+\mathrm{h}_{\mathrm{r} 23}\left(\mathrm{~T}_{\mathrm{ap}}-\mathrm{T}_{\mathrm{bp}}\right)+\mathrm{h}_{3}\left(\mathrm{~T}_{\mathrm{ap}}-\mathrm{T}_{\mathrm{f}}\right)$

Energy balance for the fluid:

$\mathrm{h}_{3}\left(\mathrm{~T}_{\mathrm{ap}}-\mathrm{T}_{\mathrm{f}}\right)=\mathrm{q}_{\mathrm{u}}+\mathrm{h}_{4}\left(\mathrm{~T}_{\mathrm{f}}-\mathrm{T}_{\mathrm{bp}}\right)$

Energy balance on the bottom plate

$$
\mathrm{h}_{\mathrm{r} 23}\left(\mathrm{~T}_{\mathrm{ap}}-\mathrm{T}_{\mathrm{bp}}\right)+\mathrm{h}_{4}\left(\mathrm{~T}_{\mathrm{f}}-\mathrm{T}_{\mathrm{bp}}\right)=\mathrm{U}_{\mathrm{b}}\left(\mathrm{T}_{\mathrm{bp}}-\mathrm{T}_{\mathrm{a}}\right)
$$

The solar radiation absorbed by the absorbing plate per unit area which is equal to the difference between the incident solar radiation and the optical loss, is calculated by:

$$
\mathrm{S}_{1}=\alpha I
$$

The convection heat transfer coefficient between the glass cover and the absorbing plate is:

$$
h_{1}=N u_{a p-c} \frac{k}{H_{c}^{\prime}}
$$


$\mathrm{H}_{\mathrm{c}}^{\prime}$ is the mean gap thickness between the cover and the absorbing $\mathrm{H}_{\mathrm{c}}^{\prime}(\mathrm{m})$ is calculated by $\mathrm{H}_{\mathrm{c}}^{\prime}=H_{c}+0.5 H_{g}$, where $H_{g}$ is the high of the v-groove absorber.

For flat plate and v-groove collector, Nusselt number for natural convection can be estimated by the following correlation:

$$
\mathrm{Nu}_{\mathrm{ap}-\mathrm{c}}=1+1.44\left[1-\frac{1708(\sin 1.8 \theta)^{1.6}}{R a \cos \theta}\right]\left[1-\frac{1708}{R a \cos \theta}\right]^{+}+\left[\left(\frac{R a \cos \theta}{5830}\right)^{173}-1\right]^{+}
$$

The equation above is valid for $0^{\circ} \leq \theta \leq 75^{\circ}$. $\mathrm{Ra}$ is the Rayleigh number, which is defined as:

$$
R a=\frac{\rho^{2} C_{p} g \beta\left(T_{a p}-T_{c}\right) H_{C}^{3}}{k \mu}
$$

Radiation heat transfer coefficients between the glass cover and the absorbing plate and between the absorbing plate is represented as:

$$
h_{r 21}=\frac{\sigma\left(T_{a p}^{2}+T_{c}^{2}\right)\left(T_{a p}+T_{c}\right)}{\frac{1}{\varepsilon_{a p}}+\frac{1}{\varepsilon_{c}}-1}
$$

The overall top loss coefficient is:

$$
U_{t}=h_{w}+h_{r s}
$$

The convection heat transfer coefficient from the glass cover due to wind is $h_{w}=5.7+$ $3.8 V_{w}$.

Radiation heat transfer coefficient from the glass cover to sky referred to the ambient air temperature $T_{a}$ can be obtained as follows:

$$
h_{r s}=\sigma \varepsilon_{c}\left(T_{c}+T_{s}\right)\left(T_{c}^{2}+T_{s}^{2}\right) \frac{\left(T_{c}-T_{s}\right)}{\left(T_{c}-T_{a}\right)}
$$

The sky temperature $T_{\mathrm{s}}$ is estimated by $T_{s}=0.0552 T_{a}^{1.5}$

The incident solar radiation absorbed by the absorbing plate is

$$
\mathrm{S}_{2} \cong 0.97 \tau_{\mathrm{c}} \alpha_{\mathrm{ap}} \mathrm{I}
$$

Nusselt number for flat-plate collector can be obtained by the equation below:

$$
\mathrm{Nu}_{\text {ap-f }}=0.0158 \mathrm{Re}^{0.8}
$$

Also, the Nusselt number for V-groove collector is estimated by the following correlation

When $R e<2800$

$$
\mathrm{Nu}_{\mathrm{ap}-\mathrm{f}}=2.821+0.126 \operatorname{Re} \frac{H_{g}}{L}
$$

When $2800 \leq \operatorname{Re} \leq 10^{4}$

$$
\mathrm{Nu}_{\mathrm{ap}-\mathrm{f}}=1.9 \times 10^{-6} R e^{1.79}+225 \frac{H_{g}}{L}
$$

When $10^{4} \leq R e \leq 10^{5}$

$$
\mathrm{Nu}_{\mathrm{ap}-\mathrm{f}}=0.0302 R e^{0.74}+0.242 R e^{0.74} \frac{\mathrm{Hg}_{\mathrm{g}}}{\mathrm{L}}
$$

Where Reynolds number for a flat plate absorber is:

$$
R e=\frac{2 \rho U_{f} H_{g}}{\mu}
$$


And Reynolds number for a v-groove plate absorber is given by

$$
R e=\frac{D \rho U_{f_{h}}}{\mu}
$$

Hydraulic diameter of the airflow channel formed by the absorbing plate and the bottom plate is $D_{h}(m)$. The hydraulic diameter for a flat plate absorber is given as

$$
D_{h}=\frac{2 W H_{g}^{\prime}}{W+H_{g}^{\prime}}=\frac{W H_{g}}{W+0.5 H_{g}}
$$

And the hydraulic diameter for a v-groove absorber is given as:

$$
D_{h}=\frac{2}{3} H_{g}
$$

The radiation heat transfer coefficients between the glass cover and the bottom plate are predicted by:

$$
h_{r 23}=\frac{\sigma\left(T_{a p}^{2}+T_{b p}^{2}\right)\left(T_{a p}+T_{b p}\right)}{\frac{1}{\varepsilon_{a p}}+\frac{1}{\varepsilon_{b p}}-1}
$$

The convection heat transfer coefficients for the fluid moving on the absorbing plate and on the bottom plate are calculated by:

$$
h_{3}=N u_{a p-f} \frac{k}{D_{h}}
$$

The conductive heat transfer coefficient between the second pass fluid and the bottom plate is assumed to be equal, therefore,

$$
h_{4}=h_{3}
$$

The heat gain equation is given as: $q_{u}=\gamma\left(T_{f a}-T_{f i}\right)$, where, $\gamma=C_{p} \dot{m}_{f}$

The conduction heat transfer coefficient across the insulation is estimated by:

$$
U_{b}=\frac{k_{i}}{\Delta_{i}}
$$

Finally, the collector efficiency can be determined by:

$$
\eta=\frac{m C_{p}\left(T_{0}-T_{f i}\right)}{I}
$$

The data below are for $\mathrm{T}$ from $280 \mathrm{~K}$ to $470 \mathrm{~K}$. The following empirical correlations can be used to estimate the air density:

$$
\rho=3.9147-0.016082 \mathrm{~T}+2.9013 \times 10^{-5} \mathrm{~T}^{2}-1.9407 \times 10^{-8} \mathrm{~T}^{3}
$$

Thermal conductivity: $\mathrm{k}=\left(0.0015215+0.097459 \mathrm{~T}-3.3322 \times 10^{-5} \mathrm{~T}^{2}\right) \times 10^{-3}$

and dynamic viscosity: $\mu=\left(1.6157+0.06523 \mathrm{~T}-3.0297 \times 10^{-5} \mathrm{~T}^{2}\right) \times 10^{-6}$

also, $\beta=\frac{1}{\mathrm{~T}}(1 / \mathrm{K})$ and $\mathrm{C}_{\mathrm{p}} \cong 1000 \mathrm{~J} / \mathrm{kg}$. K can be assumed.

\subsection{Flat Plate and V-groove Collector Double Pass Equations and Results}

The thermal network for double-pass solar air collector is illustrated in Fig. 6. The equations from [8] will be used to calculate the thermal performance using the matrix method.

Energy balance equation for the top cover:

$$
S_{1}+h_{r 21}\left(T_{\mathrm{ap}}-T_{\mathrm{c}}\right)+h_{1}\left(T_{f 1}-T_{\mathrm{c}}\right)=U_{t}\left(T_{\mathrm{c}}-T_{a}\right)
$$


Energy balance equation for the fluid's first pass:

$h_{2}\left(T_{\mathrm{ap}}-T_{f 1}\right)=h_{1}\left(T_{f 1}-T_{\mathrm{c}}\right)+Q_{1}$

Energy balance equation for the absorber plate:

$S_{2}=h_{3}\left(T_{a p}-T_{f 2}\right)+h_{2}\left(T_{a p}-T_{f 1}\right)+h_{r 23}\left(T_{a p}-T_{b p}\right)+h_{r 21}\left(T_{a p}-T_{c}\right)$

Energy balance equation for the fluid's second pass:

$h_{3}\left(T_{\mathrm{ap}}-T_{f 2}\right)=h_{4}\left(T_{f 2}-T_{\mathrm{bp}}\right)+Q_{2}$

Energy balance equation for the bottom plate:

$$
h_{4}\left(T_{f 2}-T_{b p}\right)+h_{r 23}\left(T_{a p}-T_{b p}\right)=U_{b}\left(T_{b p}-T_{a}\right)
$$

The amount of heat transferred in the first pass fluid and the second pass fluid are calculated as:

$$
\begin{aligned}
& Q_{1}=2 m C_{p}\left(T_{f 1}-T_{f i}\right) \\
& Q_{2}=2 m C_{p}\left(T_{f 2}-T_{f 1}\right) .
\end{aligned}
$$

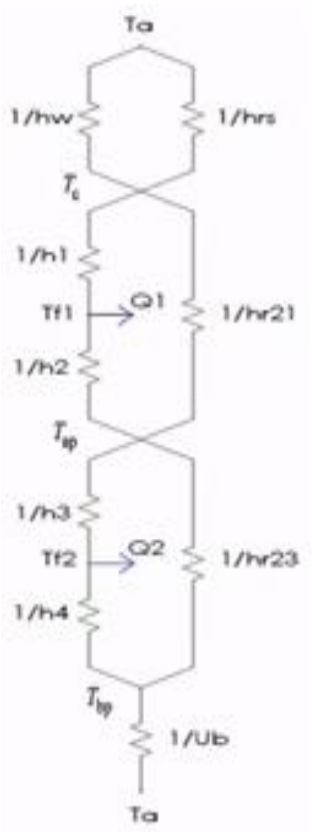

Fig. 6: Thermal network of a double-pass solar air collector.

\section{RESULTS AND DISCUSSION}

The simulations were run at the same operating condition to identify the thermal efficiency of each collector. The simulations were done for the operating conditions listed below in Table.1.

Figure 7 represents the variation of the efficiency and output temperature of the collector with the mass flow rate. For the outlet temperature, as the flow rate increases the air does not get much time to capture the solar heat. Thus, the temperature has reverse relation with the flow rate which is also affirmed in Fig. 7. For the case of efficiency, there is an initial increase with flow rate but after $0.02 \mathrm{~kg} / \mathrm{m}^{2} \mathrm{~s}$, the efficiency is almost constant. These two curve trends are true for all the four collectors, as observed in Fig. 7 and Fig. 8. 
Table 1: Initial parameters for simulation.

\begin{tabular}{cccccc}
\hline Parameter & Value & Unit & Parameter & Value & Unit \\
\hline $\boldsymbol{I}$ & 600 & $\mathrm{~W} / \mathrm{m}^{2}$ & $\boldsymbol{\varepsilon}_{\boldsymbol{a} \boldsymbol{p}}$ & 0.94 & -- \\
$\boldsymbol{\theta}$ & 30 & degrees & $\boldsymbol{\varepsilon}_{\boldsymbol{b} \boldsymbol{p}}$ & 0.9 & -- \\
$\boldsymbol{W}$ & 1 & $\mathrm{~m}$ & $\boldsymbol{\varepsilon}_{\boldsymbol{c}}$ & 0.94 & -- \\
$\boldsymbol{L}$ & 2 & $\mathrm{~m}$ & $\boldsymbol{\alpha}_{\boldsymbol{a} \boldsymbol{p}}$ & 0.06 & -- \\
$\boldsymbol{H}_{\boldsymbol{g}}$ & 0.05 & $\mathrm{~m}$ & $\boldsymbol{\alpha}_{\boldsymbol{c}}$ & 0.95 & -- \\
$\boldsymbol{H}_{\boldsymbol{c}}$ & 0.025 & $\mathrm{~m}$ & $\boldsymbol{\tau}_{\boldsymbol{c}}$ & 0.84 & -- \\
$\boldsymbol{m}$ & 0.035 & $\mathrm{~kg} / \mathrm{m}^{2} \mathrm{~s}$ & $\boldsymbol{V}_{\boldsymbol{w}}$ & 1 & $\mathrm{~m} / \mathrm{s}$ \\
$\boldsymbol{T}_{\boldsymbol{a}}$ & 300 & $\mathrm{Kelvins}$ & $\boldsymbol{\sigma}$ & $5.67 \mathrm{E}-08$ & $\mathrm{~W} / \mathrm{m}^{2} \mathrm{~K}^{4}$ \\
$\boldsymbol{T}_{\boldsymbol{f} \boldsymbol{i}}$ & 300 & $\mathrm{Kelvins}$ & $\boldsymbol{g}$ & 9.81 & $\mathrm{~m} / \mathrm{s}^{2}$ \\
$\boldsymbol{k}_{\boldsymbol{i}}$ & 0.025 & $\mathrm{~W} / \mathrm{mK}$ & $\boldsymbol{U}_{\boldsymbol{f}}$ & 1 & $\mathrm{~m} / \mathrm{s}$ \\
\hline
\end{tabular}

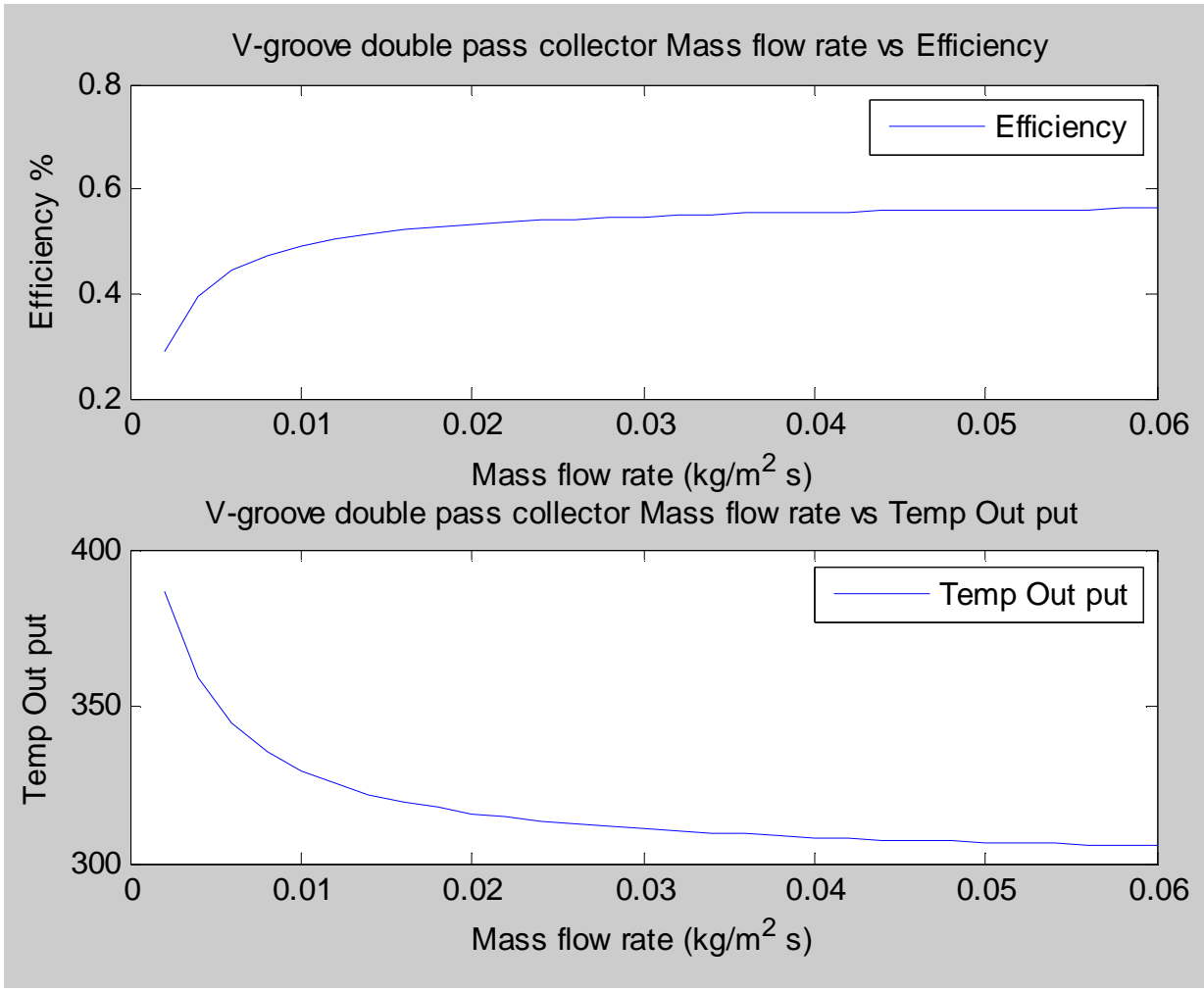

Fig. 7: Performance analysis of V-groove Double Pass collector.

Figure 8 represents the variation of the outlet temperature for the four types of collectors. It is noticed that at higher flow rate the output temperature is almost similar for all the collectors. But for lower flow rate, the V-grove double pass collector clearly provides a better output with the maximum temperature of 385 Kelvin. Another observation from Fig. 8 is that the Double Pass Flat pate collector and Single Pass Vgroove collector has similar thermal performance with mass flow rate. This indicates the better productivity through the v-groove corrugated absorber plate. 


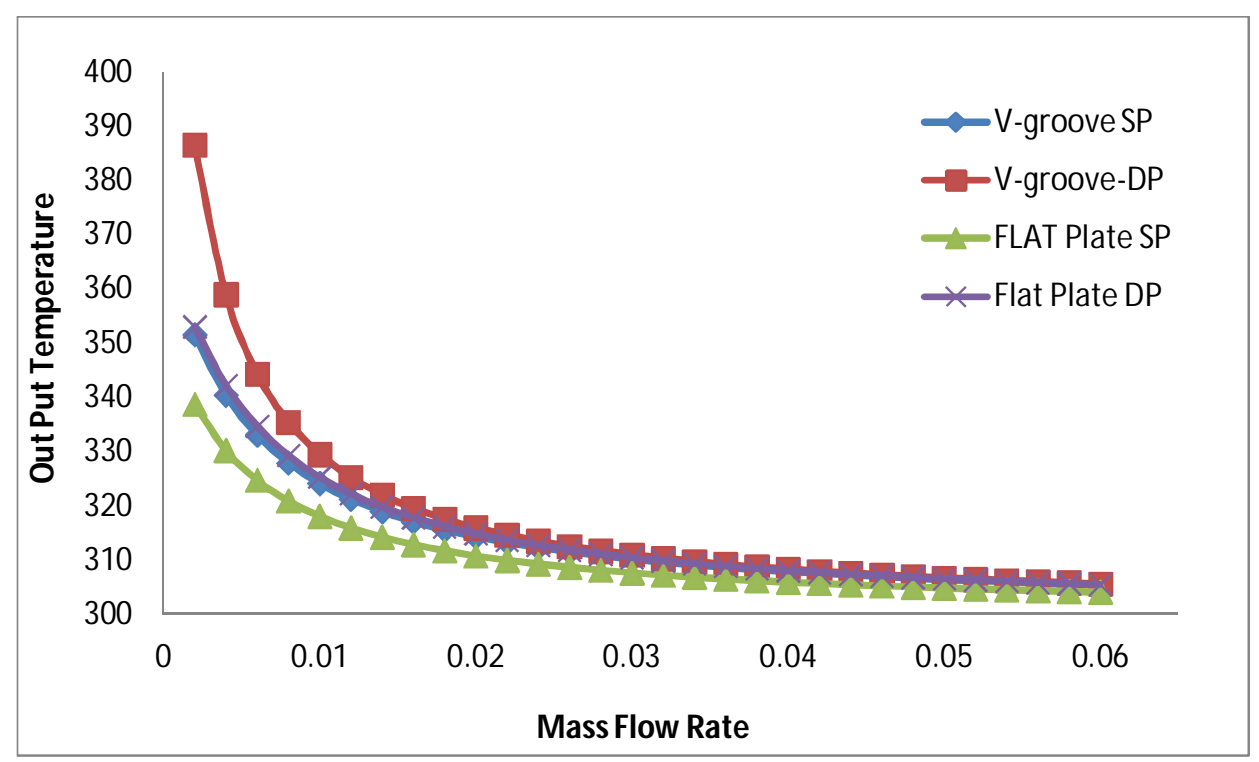

Fig. 8: Outlet temperature comparison for the four types of collectors.

Figure 9 represents the variation of the efficiency for the four types of collectors. The flat plate single pass flow collector has efficiency of $41 \%$, flat plate double pass flow collector has efficiency of 55\%, v-groove single pass flow collector has efficiency of $54 \%$ and v-groove double pass flow collector has efficiency of 56\%. It is concluded from the results that v-groove double pass flow collector has the highest efficiency value due to the larger contacting area created by the v-groove absorber. In this case the air is in contact with the absorber from both sides.

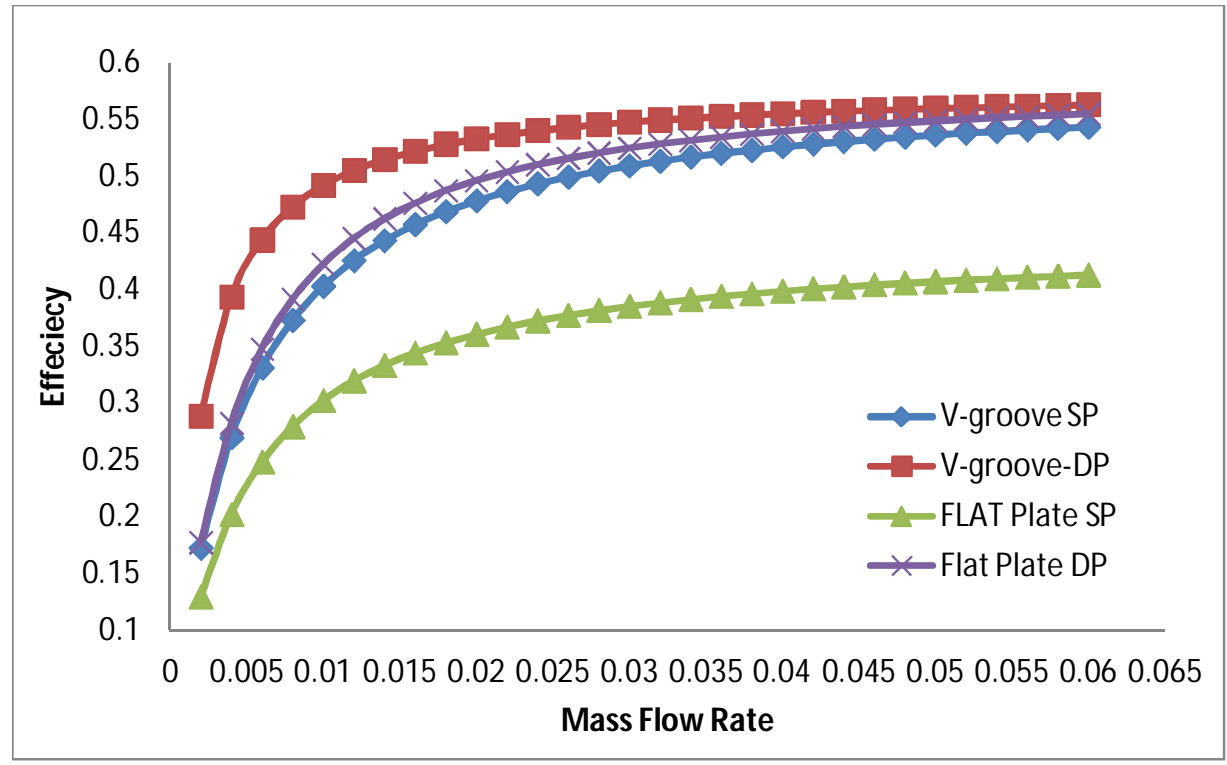

Fig. 9: Efficiency comparison for the four type of collector.

The comparative relation of solar radiation and mass flow rate on thermal performance for v-groove double pass collector is represented in Fig. 10 and Fig. 11. In Fig. 10, the radiation has a positive impact on output whereas flow rate has a negative impact on output. From Fig. 10 it is further observed that flow rate dominates more on the 
output temperature. As in Fig. 10, slope for 'Output Temperature vs. Mass Flow rate' is steeper than 'Output Temperature vs. Radiation'.

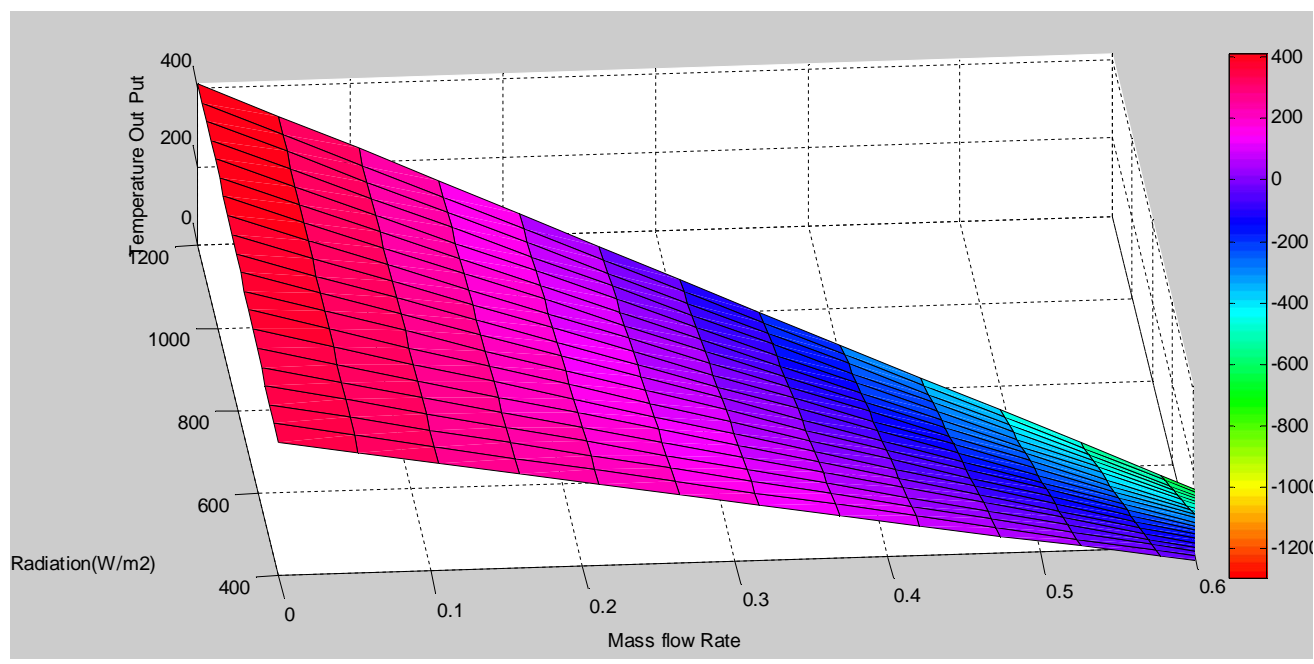

Fig. 10: Variation of Output Temperature with radiation and mass flow rate for Vgroove collector.

For case of efficiency as shown as Fig. 11, the relation is not as straight forward as the radiation is embedded in the efficiency formula. Figure 11 shows that there are some optimum points, and this may be further studied.

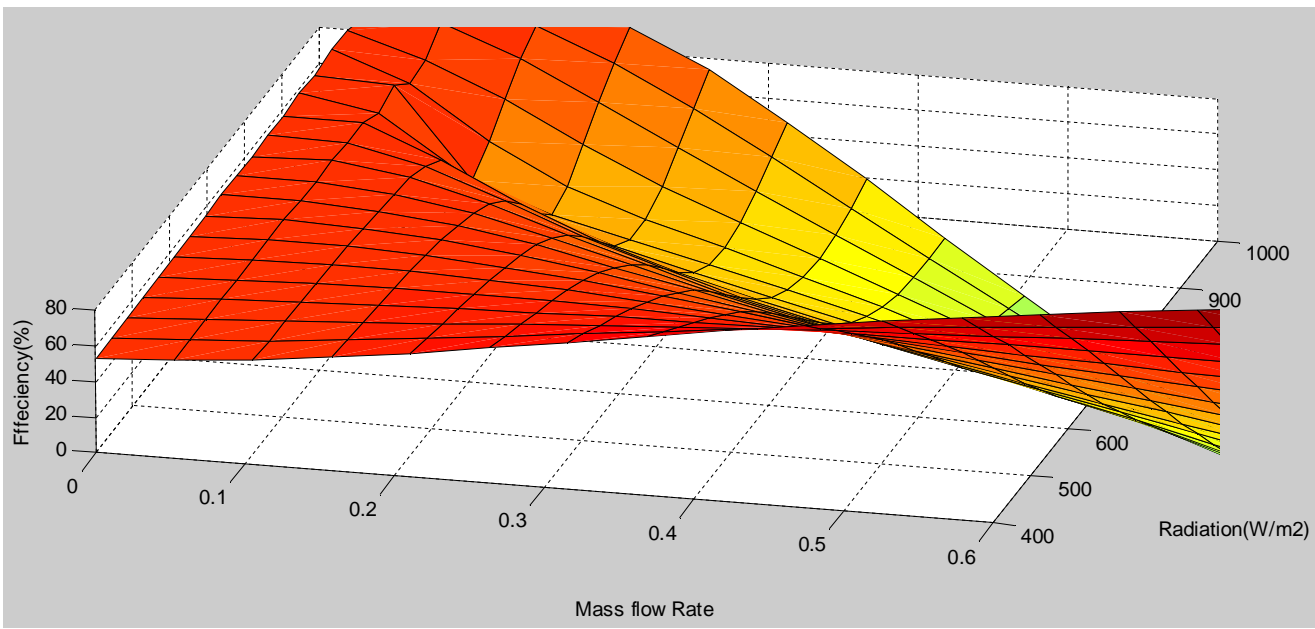

Fig. 11: Variation of Efficiency with radiation and mass flow rate for V-groove collector.

\section{CONCLUSION}

Performance curves of flat plate and v-groove collectors with single and double pass have been obtained. These include the effects of mass flow rate and solar radiation on output temperature and efficiency of the solar collector. The results show that v-groove double pass collector has the highest efficiency. Lastly, from the comparative study on the effects of flow rate and radiation, the thermal performance of the solar collector is found to be strongly dependent on the flow rate. 


\section{REFERENCES}

[1] Karim MA, Hawlader MNA. (2004) Development of solar air collectors for drying applications. Energy Conversion and Management, 45:329-344.

[2] Tchinda R. (2009) A review of the mathematical models for predicting solar air heater systems. Renewable and Sustainable Energy Reviews, 13:1734-1759.

[3] Liu T, Lin W, Gao W, Luo C, Li M, Zheng Q, Xia C. (2007) A parametric study on the thermal performance of a solar air collector with a v-groove absorber. International Journal of Green Energy, 4(6): 601-622

[4] Karim MA, Hawlader MNA. (2006) Performance evaluation of v-groove solar air collector for drying applications. Applied Thermal Engineering, 26:121-130.

[5] Tiwari GN, Mishra RK. (2012) Advanced Renewable Energy Sources, CB4 0WF, RSC Publishing Thomas Grahman House, Cambridge, UK.

[6] Cengel Y, Boles M. (2005) Thermodynamics: An Engineering Approach, 5th ed., McGrawHill College, Boston.

[7] Hastings SR, Mørck O. (2000) Solar air systems: A design handbook. Colorado State University, USA.

[8] Ong KS. (1995) Thermal performance of solar air heaters: Mathematical model and solution procedure. Solar Energy, 55:93-109.

[9] Duffie JA, Backman WA. (2006) Solar Engineering of Thermal Processes, 3rd ed., Wiley, New York.

[10] Schumann TEW. (1929) Heat transfer: A liquid flowing through a porous prism. Journal of the Franklin Institute, 208(3):405-416.

\section{NOMENCLATURE}

Solar insolation rate incident on the glass cover $\left(\mathrm{W} / \mathrm{m}^{2}\right)$

$\tau_{\mathrm{c}} \quad$ Transmissivity of solar radiation of the glass cover

$\alpha_{\mathrm{ap}} \quad$ Absorptivity of solar radiation of the absorbing plate

$\mathrm{S} \quad$ solar radiation absorbed by glass cover and absorber plate $\left(\mathrm{W} / \mathrm{m}^{2}\right)$

$\mathrm{q}_{\mathrm{u}} \quad$ Energy gain $\left(\mathrm{W} / \mathrm{m}^{2}\right)$

$H_{c} \quad$ Gap between v-groove absorber and glass cover $(m)$

$H_{g} \quad$ Height of v-groove $(m)$

$T_{s} \quad$ Sky temperature $(\mathrm{k})$

$T_{c} \quad$ Mean temperature on the glass cover $(\mathrm{k})$

$T_{a p} \quad$ Mean temperature on the absorbing plate (k)

$T_{f} \quad$ Mean air temperature $(\mathrm{k})$

$T_{b p} \quad$ Mean temperature on the bottom plate $(\mathrm{k})$

$T_{a} \quad$ Ambient air temperature (k)

$T_{f i} \quad$ Inlet temperature (k)

$T_{f o} \quad$ Outlet temperature (k)

$\mathrm{q}_{\mathrm{u}} \quad$ Heat transferred to the air $\left(W / \mathrm{m}^{2}\right)$

$\mathrm{C}_{\mathrm{p}} \quad$ Specific heat of air $(\mathrm{J} / \mathrm{kgK})$

$\dot{\mathrm{m}}_{\mathrm{f}} \quad$ Air mass flow rate per unit area of collector 
$\mathrm{h}_{1} \quad$ Thermal losses to the glass cover by natural convection

$h_{r 21} \quad$ Thermal losses to the glass cover by thermal radiation $\left(\mathrm{W} / \mathrm{m}^{2} \mathrm{~K}\right)$

$\mathrm{h}_{\mathrm{r} 23} \quad$ Thermal losses to the glass cover by the bottom plate by thermal radiation $\left(\mathrm{W} / \mathrm{m}^{2} \mathrm{~K}\right)$

$\mathrm{h}_{4} \quad$ Convection heat transfer coefficient of fluid on the bottom plate $\left(\mathrm{W} / \mathrm{m}^{2} \mathrm{~K}\right)$

$\mathrm{h}_{\mathrm{w}} \quad$ Convection heat transfer coefficient from the glass cover due to wind $\left(\mathrm{W} / \mathrm{m}^{2} \mathrm{~K}\right)$

$\mathrm{h}_{\mathrm{rs}} \quad$ Radiation heat transfer coefficient from the glass cover to sky $\left(\mathrm{W} / \mathrm{m}^{2} \mathrm{~K}\right)$

$\mathrm{U}_{\mathrm{b}} \quad$ Conduction heat transfer coefficient across the insulation $\left(\mathrm{W} / \mathrm{m}^{2} \mathrm{~K}\right)$

$\mathrm{h}_{3} \quad$ Convection heat transfer coefficients for the fluid (W/ $\left.{ }^{2} \mathrm{~K}\right)$

$\eta \quad$ Efficiency

$\mathrm{V}_{\mathrm{w}} \quad$ Wind velocity of the ambient air $(\mathrm{m} / \mathrm{s})$

$\sigma \quad$ Stefan-Boltzmann constant $\left(5.67 \times 10^{-8} \mathrm{~W} / \mathrm{m}^{2} \mathrm{~K}^{4}\right)$

$\varepsilon_{\mathrm{c}} \quad$ Emissivity of thermal radiation of the glass cover

$\varepsilon_{\text {ap }} \quad$ Emissivity of thermal radiation of the absorbing plate

$\varepsilon_{\text {ap }} \quad$ Emissivity of thermal radiation of the bottom plate

$\mathrm{k}_{\mathrm{i}} \quad$ Thermal conductivity

$\Delta_{\mathrm{i}} \quad$ Mean thickness of the insulation

$\mathrm{H}_{\mathrm{c}}^{\prime} \quad$ Mean gap thickness between the cover and the absorbing $(\mathrm{m})$

$\mathrm{Nu}_{\mathrm{ap}-\mathrm{c}} \quad$ Nusselt number for the natural convection

$\beta \quad$ Thermal expansion coefficient

$\mu \quad$ Dynamic viscosity of air $(\mathrm{kg} / \mathrm{m} . \mathrm{s})$

g Acceleration due to gravity $\left(\mathrm{m} / \mathrm{s}^{2}\right)$

$\mathrm{D}_{\mathrm{h}} \quad$ Hydraulic diameter $(\mathrm{m})$

W Collector width ( $\mathrm{m}$ )

$\mathrm{Nu}_{\text {ap-f }} \quad$ Nusselt number for the convection of fluid

Re Reynolds number for flat plate absorber

$\varnothing \quad$ tilt angle of the collector (degrees)

k Thermal conductivity of air (W/ m. K)

W Width of the collector ( $\mathrm{m}$ )

$\mathrm{L} \quad$ Length of the collector ( $\mathrm{m}$ ) 